UNIWERSYTET

SZCZECINSSKI

Zeszyty

Naukowe

n r 858
Wspótczesne

Problemy

Ekonomiczne

$n r 11(2015)$

DOI: 10.18276/wpe.2015.11-04

\title{
Agnieszka Łopatka*
}

\section{Ekonomia dobrobytu. Rachunki narodowe w kontekście pomiaru dobrobytu}

\author{
Bogactwo jest produktem pracy \\ John Locke
}

Słowa kluczowe: dobrobyt, HDI, produkt krajowy brutto

Keywords: prosperity, HDI, gross domestic product

\section{Wprowadzenie}

Dobrobyt jest pojęciem niezwykle złożonym. Jego natura jest zgłębiana od wieków zarówno przez ekonomistów, jak i filozofów, których teorie wymagają komparacji. Pomiar dobrobytu w ujęciu ekonomicznym nie może polegać jedynie na mierzeniu rozwoju gospodarczego państwa, bowiem gwarancja wysokiej jakości życia obywateli nie opiera się tylko i wyłącznie na pomnażaniu majątku.

Szeroko rozumiany dobrobyt jest pojęciem wyrażającym relację pomiędzy ekonomią a społeczeństwem oraz między aktywnością zmierzającą do produkcji bogactwa a jego wykorzystaniem. Już w 1934 roku laureat Nagrody Nobla S.S. Kuznets zwrócił uwagę Kongresu Stanów Zjednoczonych, iż ,dobro narodu może mieć słaby związek z dochodem narodowym"1. Dlatego też od dziesięcioleci poszukuje się alternatywnych metod pomiaru tego, co jest naprawdę wartościowe.

Próby sformułowania definicji dobrobytu wykazują powstawanie licznych kontrowersji, a przedmiotem ciągłej dyskusji jest to, co powinno być wkalkulowane w rachunek

\footnotetext{
* Magister Agnieszka Łopatka jest doktorantką na Wydziale Zarządzania i Ekonomiki Usług (Katedra Ekonomii) Uniwersytetu Szczecińskiego. E-mail: Agnieszka.lopatka@wzieu.pl.

1 C. Cobb, T. Halstead, J. Rowe, If the GDP is Up, Why is America Down?, Washington 1995.
} 
dobrobytu. Szczęście, zadowolenie z życia czy też jakość życia oraz kapitał społeczny należą do zagadnień, które najczęściej pojawiają się w tym kontekście². Rozległy zakres badanej problematyki wskazuje, iż istnieją poważne trudności w określeniu i zdefiniowaniu wszystkich wskaźników i zmiennych odnoszących się do dobrobytu. Różnorodne sposoby badania dobrobytu pozwalają jednak na wyodrębnienie problemów, które powinny być przedmiotem analizy teoretycznej, a następnie działań praktycznych.

Celem niniejszego artykułu jest zbadanie, czy produkt krajowy brutto jest optymalnym wskaźnikiem dobrobytu ekonomicznego, oraz sprawdzenie, która z dostępnych alternatyw dla PKB najlepiej odzwierciedla dobrobyt jednostek oraz społeczeństw.

\section{Ekonomia dobrobytu w ujęciu teoretycznym}

W obszarze nauk ekonomicznych podejmowane są liczne próby określenia poziomu dobrobytu poszczególnych państw czy regionów, niemniej jednak definicja dobrobytu jest pojęciem nieprecyzyjnym, a także zjawiskiem wielowymiarowym i zarazem niezwykle subiektywnym. Pomimo wciąż rosnącego zainteresowania koncepcją dobrobytu w literaturze przedmiotu nie istnieje jednoznaczne określenie charakteryzujące tę kategorię. Wynika to między innymi z jego złożoności.

Ekonomia dobrobytu stanowi gałąź ekonomii skupiającą się na zagadnieniach normatywnych, w tym przede wszystkim na sposobie organizacji gospodarki. To teoretyczny nurt głoszący, iż w gospodarce rynkowej konieczna jest ingerencja państwa kształtująca w taki sposób stosunki podziału, aby każda jednostka mogła osiągnąć odpowiedni udział w dobrobycie. Pierwszym teoretycznym dziełem w zakresie ekonomii dobrobytu była praca A.C. Pigou Bogactwo i dobrobyt, która następnie została uzupełniona i rozszerzona w 1920 roku i opublikowana pod tytułem Ekonomia dobrobytu³. Należy podkreślić, iż do połowy XX wieku jakość życia była traktowana jako kategoria socjologiczna i psychologiczna, jednak rozwój gospodarczy krajów po II wojnie światowej doprowadził do traktowania pojęcia dobrobytu w kategoriach ekonomicznych. Założenia określone przez Pigou okazały się zbyt wąskie do określenia ram dobrobytu społecznego. Kolejne pokolenia ekonomistów stworzyły nową ekonomię dobrobytu, która odrzuciła mierzalną koncepcję użyteczności na rzecz koncepcji użyteczności porządkowej oraz wprowadziła pojęcie społecznej funkcji dobrobytu ${ }^{4}$. Normatywny charakter ekonomii dobrobytu sprowadza się do oceny efektywności alokacji zasobów oraz sprawiedliwości podziału dóbr pomiędzy poszczególne podmioty gospodarcze.

\footnotetext{
T. Drabsch, Measuring Wellbeing, Briefing Paper no. 4/2012, Sydney 2012. www.biznes.pwn.pl/haslo/3897006/ekonomia-dobrobytu.html (25.06.2014). Tamże.
} 
Włoski ekonomista i socjolog V. Pareto stworzył pojęcie określane jako efektywność Pareto, zaliczane do najważniejszych koncepcji w ekonomii, interpretujące efektywność jako sytuację, w której nie można polepszyć sytuacji żadnej jednostki, nie pogarszając jednocześnie sytuacji kogoś innego ${ }^{5}$. Takie rodzaje alokacji zasobów, w przypadku których nie da się poprawić sytuacji danej jednostki bez jednoczesnego pogorszenia innej, określane są jako efektywne w rozumieniu Pareto lub optymalne w sensie Pareto ${ }^{6}$.

Do podstawowych twierdzeń ekonomii dobrobytu zalicza się dwa obejmujące związek wolnokonkurencyjnych rynków z efektywnością Pareto. Pierwsze z nich wskazuje, iż jeśli gospodarka jest konkurencyjna, to wówczas jest efektywna w rozumieniu Pareto. Twierdzenie drugie natomiast podkreśla istnienie wielu wariantów podziału dochodu, które są efektywne w sensie Pareto. Według Pareto każdą efektywną alokację można osiągnąć dzięki wykorzystaniu zdecentralizowanego mechanizmu rynkowego, w którym decyzje o produkcji i konsumpcji podejmują poszczególne podmioty, z których składa się gospodarka?.

Istotne wydaje się zwrócenie uwagi na fakt, iż teoria ekonomii dobrobytu powstała w warunkach konkurencji doskonałej. Zupełnie inne zależności zachodzą jednak w przypadku pozostałych struktur rynkowych. W związku z tym z krytyki idei teorii dobrobytu wyłoniły się dwa nurty. Amerykański ekonomista postkeynesowski A. Lerner wykazał, iż interwencja państwa może doprowadzić do zachowania proporcji w wielkościach marginalnych i jednocześnie przyczynić się do kształtowania społeczeństwa dobrobytu. Drugi nurt natomiast to teoretyczna wizja gospodarki socjalistycznej reprezentowana przez O.a Langego, według którego centralny planista państwa za pomocą metody prób i błędów zapewni spełnienie wszystkich marginalnych warunków określających funkcję dobrobytu.

Zarówno ekonomiści, socjologowie, jak i psychologowie na całym świecie od lat pracują nad stworzeniem jednego precyzyjnego miernika dobrobytu społeczno-ekonomicznego. W efekcie tych działań powstają różnego rodzaju mierniki o zróżnicowanym zastosowaniu praktycznym. W 2009 roku Komisja do Rady i Parlamentu Europejskiego pod kierownictwem J. Stiglitza stworzyła raport, w którym opublikowano postulat opracowania dodatkowych wskaźników opisujących dobrobyt jednostki i społeczeństw oraz zrównoważony rozwój ekonomiczny, społeczny i ekologiczny9 . Pomimo jednak licznych opracowań i badań w aspekcie oceny dobrobytu i jakości życia nie znaleziono do tej pory uniwersalnej miary.

\footnotetext{
P.A. Samuelson, W.D. Nordhaus, Ekonomia 2, Wydawnictwo Naukowe PWN, Warszawa 1999, s. 183.

J.E. Stiglitz, Ekonomia sektora publicznego, Wydawnictwo Naukowe PWN, Warszawa 2004, s. 69-70.

Tamże, s. 72-73.

www.biznes.pwn.pl/haslo/3897006/ekonomia-dobrobytu.html (26.06.2014.

www.firma.egospodarka.pl/44958,Miary-dobrobytu-wg-Stiglitza,1,11,1.html (26.06.2014).
} 


\section{Rachunki narodowe i pomiar dobrobytu}

Dobrobyt ekonomiczny jest pojęciem niezwykle złożonym. W ramach ekonomii podejmowane są liczne próby określenia jego poziomu i struktury. Jednym ze wskaźników stosowanych do jego pomiaru jest produkt krajowy nrutto (gross domestic product GDP). Stanowi on wartość rynkową dóbr finalnych powstałych w ciągu roku w danym $\mathrm{kraju}^{10}$. Problematyka definicji produktu i celu działalności gospodarczej, dawniej określana mianem ekonomiki, stanowiła przedmiot rozważań i dyskusji już w starożytnej Grecji. Już wówczas powstało pojęcie ,nadwyżka”, które jednak nie do końca zostało jasno zdefiniowane. Twierdzono ówcześnie, że wynika ona z tytułu posiadania ziemi i niewolników, a grecki myśliciel Ksenofont wskazywał, że celem ekonomiki jest osiąganie nadwyżki, którą utożsamiał $\mathrm{z}$ bogactwem ${ }^{11}$.

Wśród składników PKB wyróżnia się konsumpcję, inwestycje, wydatki państwa i eksport netto. Jeśli chodzi o konsumpcję, to stanowi ona wydatki gospodarstw domowych na dobra i usługi z wyjątkiem nakładów na zakup nowych domów lub mieszkań. Do inwestycji natomiast zaliczane są wydatki na zakup maszyn i urządzeń, budynków i budowli (w tym zakupy mieszkań oraz domów przez gospodarstwa domowe), czyli ogólnie rzecz ujmując - na zakupy dóbr, które w przyszłości zostaną zużyte do wytwarzania innych dóbr i usług. Tymczasem wydatki państwa obejmują wydatki na zakup dóbr i usług ponoszone przez władze lokalne i rząd centralny. Uwzględniają one wynagrodzenia pracowników zatrudnionych przez państwo i wydatki na prace publiczne. Do składników PKB wliczany jest również eksport netto definiowany jako suma wydatków dokonywanych przez cudzoziemców na dobra produkowane w kraju pomniejszona o wydatki na dobra wytworzone za granicą poniesione przez mieszkańców danego $\mathrm{kraju}^{12}$. Są to transakcje zawierane pomiędzy rezydentami i nierezydentami, a za moment rejestracji uznaje się przekazanie prawa własności.

Sposoby pomiaru rozmiarów aktywności rynku odgrywają istotną rolę w ekonomii, bowiem na nich opierają się decyzje wyboru kierunków polityki gospodarczej dokonywane przez rząd. W przypadku PKB wyróżnia się ujęcie realne i nominalne. Realny PKB wyrażany jest za pomocą cen stałych, zaś PKB nominalny jest liczony w cenach bieżących. Wskaźnikiem odzwierciedlającym zmiany cen wszystkich dóbr jest deflator PKB formułowany jako stosunek nominalnego PKB do PKB w ujęciu realnym ${ }^{13}$.

10 B. Czarny, Podstawy ekonomii, PWE, Warszawa 2011, s. 348.

${ }_{11}$ L. Zienkowski, Co to jest PKB? Jego rola w analizach ekonomicznych i prognozowaniu, Elipsa, Warszawa 2001, s. 7.

12 N.G. Mankiw, M.P. Taylor, Makroekonomia, PWE, Warszawa 2009, s. 37-38.

13 A. Grzelak, Makroekonomia w procesie integracji z Uniq Europejskq, Wyższa Szkoła Integracji Europejskiej w Szczecinie, Szczecin 2002, s. 41. 
Jeśli zaś chodzi o metody obliczania PKB, to zalicza się do nich ${ }^{14}$ :

a) mierzenie PKB przez sumowanie wydatków rozumiane jako ogół całkowitych wydatków na dobra i usługi w dowolnym okresie składające się z takich elementów, jak konsumpcja, inwestycje, zakupy rządowe oraz eksport netto;

b) mierzenie PKB poprzez sumowanie dochodów polegające na sumowaniu wartości wszystkich oficjalnych dochodów podmiotów uczestniczących w procesie tworzenia produktu krajowego;

c) mierzenie PKB przez sumowanie wartości produkcji.

W wyniku akcesji Polski do Unii Europejskiej nastąpił dynamiczny rozwój gospodarczy, a polska gospodarka znalazła się na szybkiej ścieżce wzrostu ${ }^{15}$. Stabilny i zrównoważony charakter wzrostu gospodarczego spowodował, iż polska gospodarka pozostała jedyną spośród krajów Unii, która nie zanotowała spadku produkcji w okresie ostatniego światowego kryzysu. Kształtowanie się dynamiki PKB w latach 2002-2013 w Polsce na tle Unii Europejskiej przedstawiono na rysunku 1.

Rysunek 1. Dynamika realnego PKB w Polsce i Unii Europejskiej w latach 2002-2013 (w \% w porównaniu do roku poprzedniego)
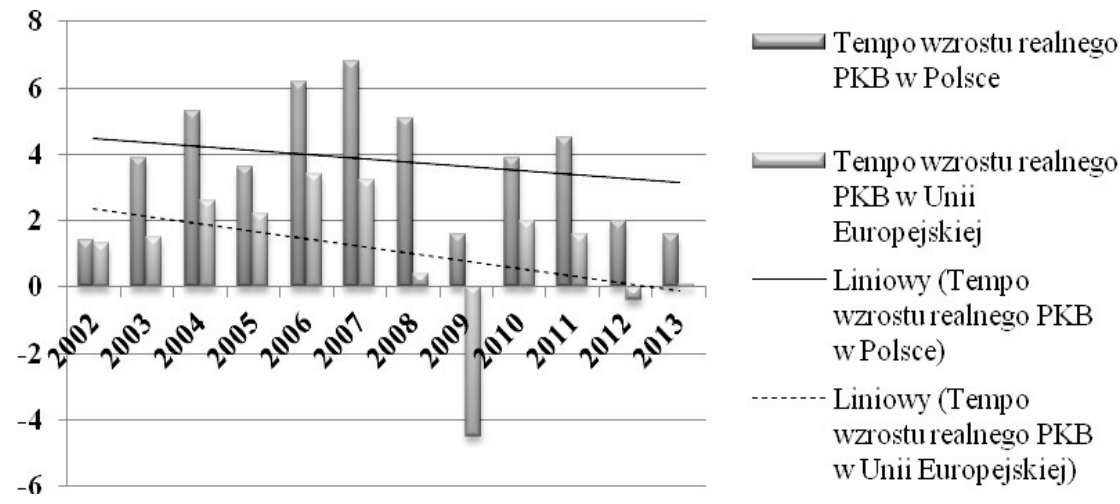

Źródło: opracowanie własne na podstawie danych Eurostatu.

Na podstawie rysunku 1 można zaobserwować, iż polska gospodarka po ustąpieniu okresów przejściowych związanych przede wszystkim z cyklem zapasów osiągnęła swoje apogeum w 2007 roku. W kolejnych latach jednak zaczęła odczuwać skutki światowego kryzysu oraz jego konsekwencje dla gospodarek rozwiniętych. Pomimo tego, iż była ona najbardziej odporna na zaburzenia kryzysowe, to jednak tempo wzrostu znacząco spadło, głównie w wyniku dostosowania zapasów i inwestycji. Czynnikiem

14 Tamże, s. 42-47.

15 www.mg.gov.pl/files/upload/8436/RoG20130829.pdf (27.06.2014). 
stabilizującym koniunkturę okazały się nakłady na inwestycje publiczne, jak również wymiana międzynarodowa ${ }^{16}$.

Spowolnienie wywołane kryzysem gospodarczym osiągnęło najniższy poziom w czwartym kwartale 2008 roku. Należy zauważyć, że postępujące od roku 2009 ożywienie miało charakter ograniczony, a szczyt aktywności polska gospodarka osiągnęła w drugim kwartale 2011 roku. Jednakże z końcem tego roku następowało powolne osłabienie w gospodarce, aby dno cyklu osiągnąć w ostatnim kwartale 2012 roku, w którym wystąpiła stagnacja. Ponowny, powolny wzrost aktywności gospodarczej zaobserwowano od pierwszego kwartału 2013 roku. Stabilny i trwały wzrost polskiej gospodarki spowodował, że poziom PKB w 2012 roku był o 12,8\% wyższy w stosunku do roku 2008, w którym to nastąpiło ujawnienie efektów kryzysu. Niemniej jednak wzrost PKB w 2013 roku był nieco wolniejszy w porównaniu z rokiem poprzednim.

W przypadku całej Unii Europejskiej poziom realnego PKB na przestrzeni omawianego okresu kształtuje się niekorzystnie, zwłaszcza w roku 2009, kiedy to gospodarki poszczególnych państw Wspólnoty poddawane były pierwszej fali kryzysu. W roku tym dynamika PKB osiągnęła swój najniższy poziom, czyli spadek do poziom -4,5\% w porównaniu z rokiem poprzednim. Jednak w kolejnych latach widoczna jest stopniowa poprawa poziomu rozwoju gospodarczego, w tym również dobrobytu. W 2012 roku w Unii odnotowano niestety dalsze wyhamowanie dynamiki PKB w porównaniu $\mathrm{z}$ rokiem 2011.

Po zakończeniu II wojny światowej prekursorzy mierzenia produkcji i dochodu narodowego podkreślali znaczenie ekspansji społecznej, a wzrost gospodarczy i dobrobyt stały się głównymi celami gospodarek poszczególnych państw. Do dziś za jedną z podstawowych miar rozwoju i dobrobytu traktuje się oprócz PKB także PKB per capita. Jest to wskaźnik wykorzystujący wartość PKB danego państwa dzieloną przez liczbę jego mieszkańców. Dzięki niemu możliwe staje się dokonanie podziału na kraje wysoko (PKB per capita powyżej 10000 USD), średnio (PKB per capita pomiędzy 2000 a 10000 USD) oraz słabo rozwinięte (PKB per capita poniżej 2000 USD) ${ }^{17}$. Poziom PKB per capita w Polsce zaprezentowano na rysunku 2.

Na podstawie rysunku 2 zauważyć można, iż wskaźnik PKB per capita w Polsce w badanym okresie sukcesywnie wzrasta. Po raz pierwszy od setek lat Polska ma realną szansę dorównania najbogatszym gospodarkom światowym. Dzięki założeniom konwergencji może rozwijać się znacznie szybciej, co w dłuższej perspektywie czasowej może doprowadzić do osiągnięcia znaczącego poziomu wzrostu gospodarczego. Pomimo kryzysu, który dotknął także polską gospodarkę, w pierwszej jego fazie widoczna jest

\footnotetext{
16 Tamże.

17 www.prognostic.pl/-/pkb-per-capita (27.06.2014).
} 
znaczna różnica wzrostu w latach 2007-2009. Od roku 2011 PKB per capita przekracza wartość 10000 USD, dzięki czemu możliwe jest zaliczanie polskiej gospodarki do kategorii krajów wysoko rozwiniętych. Jednak w porównaniu z państwami Unii Europejskiej polska gospodarka nadal zaliczana jest do słabiej rozwijających się i lokowana jest na ostatnich miejscach rankingowych.

Rysunek 2. PKB per capita według parytetu siły nabywczej w Polsce w latach 2000-2013 (w USD)

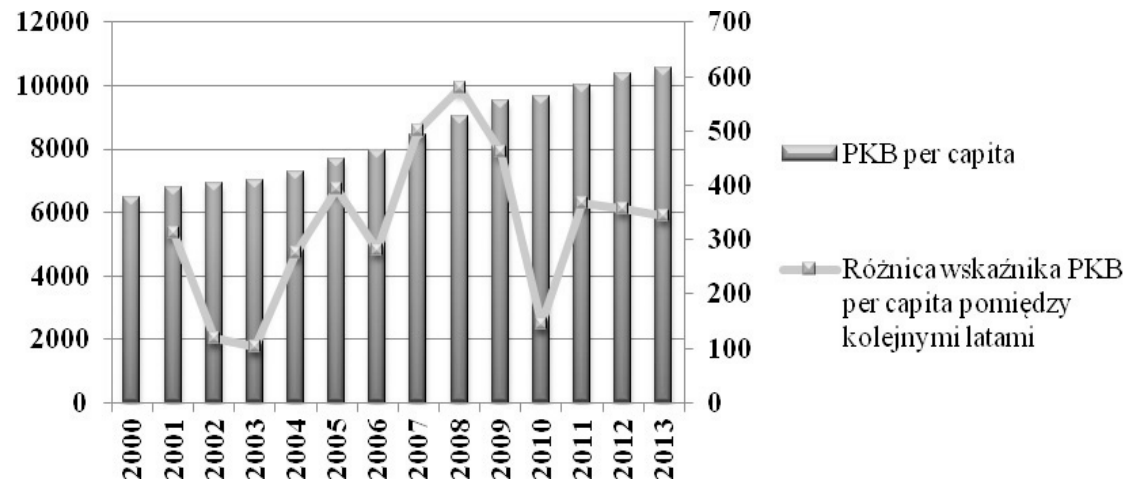

Źródło: opracowanie własne na podstawie: www.pl.tradingeconomics.com (27.06.2014).

Koncepcja PKB jako syntetycznego wskaźnika wzrostu gospodarczego oraz dobrobytu ekonomicznego zawsze była przedmiotem krytyki, jednak ostatnie lata spowodowały jej coraz większe nasilenie wynikające $\mathrm{z}$ gwałtownych przemian rzeczywistości gospodarczej spowodowanych przez światowy kryzys ekonomiczny. Dodatkowym czynnikiem kwestionowania przydatności tej kategorii rachunku narodowego było niewątpliwie załamanie się dotychczasowej ortodoksji ekonomicznej wyrażającej się zarówno w dominujących teoriach ekonomicznych, jak i postawach polityczno-gospodarczych ${ }^{18}$. PKB uznawany jest nie tylko za niewłaściwy miernik rozwoju gospodarczego, ale również dobrobytu ekonomicznego, i co więcej - jakości życia mieszkańców danego kraju.

Wśród głównych kierunków krytyki PKB jako miernika dobrobytu wyróżnia się między innymi: pomijanie czynników nierejestrowanych przez rynek, prac domowych czy aktywności w internecie, a także użyteczności z czasu wolnego oraz wypoczynku. W rachunku tym pomijana jest również niezarobkowa działalność społeczeństwa. Ujmowane są natomiast koszty społeczne niemające wpływu na wzrost dobrobytu, takie jak wydatki państwa na obronę i administrację. W rachunku PKB nie jest także brany pod uwagę podział dochodu pomiędzy poszczególne grupy społeczne ${ }^{19}$. Oprócz tego

18 www.monitor-ekonomiczny.pl/s17/Artyku\%C5\%82y/a145/Fetysz_PKB.html (27.06.2014).

19 www.biznes.pwn.pl/haslo/3940747/mierniki-dobrobytu.html (27.06.2014). 
pomijana jest jakość świadczonych usług, w szczególności państwowych. Ujmuje się natomiast produkcję ,antydóbr” szkodzących środowisku, zdrowiu i życiu ludności, takich jak wyroby tytoniowe czy broń. Dodatkowo pomijane są efekty zewnętrzne produkcji w postaci zanieczyszczeń środowiska. Ponadto, wiele kontrowersji wzbudza niezaliczanie do tej miary tak zwanej szarej strefy, czyli produkcji wytwarzanej nielegalnie. Ogromna fala krytyki stworzona wokół PKB wynika z faktu, iż niesłusznie traktowany jest on jako miernik dobrobytu z powodu braku innych wskaźników ${ }^{20}$.

Próbę zbudowania miernika lepiej od PKB oddającego poziom dobrobytu w poszczególnych państwach podjęli w 1972 roku amerykańscy ekonomiści W. Nordhaus i J. Tobin. Jednym z podstawowych celów ich pracy było zaprezentowanie zależności pomiędzy wzrostem gospodarczym a dobrobytem w sensie ekonomicznym. Skonstruowali oni miernik dobrobytu ekonomicznego (measure of economic welfare - MEW) lub jak nazwali go później - dobrobytu ekonomicznego netto (net economic welfare NEW). Wskaźnik ten obejmuje trzy zmiany sposobu obliczania PKB. Przede wszystkim zmienia klasyfikację niektórych wydatków na dobra finalne i dobra pośrednie, w tym przede wszystkim wydatki państwa na obronę narodową i bezpieczeństwo wewnętrzne traktuje jako wydatki na dobra pośrednie, które należy pominąć. Następnie uwzględnia wartość czasu wolnego, jak również produkcję w gospodarstwach domowych i w gospodarce nieoficjalnej. Ponadto, pomniejsza on wartość PKB o poziom szkodliwych efektów zewnętrznych związanych z urbanizacją i uprzemysłowieniem. Badania wykazały, iż wskaźnik dobrobytu ekonomicznego netto (NEW) przewyższa PKB. Wynika to przede wszystkim z uwzględnienia w jego obliczaniu czasu wolnego ${ }^{21}$. Jednakże u schyłku XX wieku alternatywą dla PKB jako miary dobrobytu stał się wskaźnik rozwoju społecznego (Human Development Index - HDI).

W 1990 roku Program Narodów Zjednoczonych ds. Rozwoju (United Nations Development Programme - UNDP) opublikował po raz pierwszy Raport o rozwoju społecznym (Human Development Report - HDR) stanowiący istotne narzędzie budowania świadomości w aspekcie rozwoju społecznego na świecie. Jego celem jest skupienie się na rozwoju ludzkim w aspekcie długookresowego dobrobytu wykraczającym poza sferę materialną. Głównym narzędziem wykorzystywanym w HDR jest wskaźnik rozwoju społecznego (Human Development Index - HDI) ${ }^{22}$. Miara ta została opracowana przez pakistańskiego ekonomistę M. ul Haqa będącego jednym z twórców HDR.

Wprowadzenie tego wskaźnika miało istotne znaczenie, bowiem pozwoliło na uwzględnienie zmiennych pozaekonomicznych istotnych z punktu widzenia oceny zrów-

20 www.biznes.pl/magazyny/finanse/pkb-dyzurnym-chlopcem-do-bicia,5178810,magazyn-detal.html (27.06.2014).

21 B. Czarny, dz. cyt., s. 360.

22 www.undp.iq.pl/Co-robimy/Badania-rozwoju-spolecznego2 (28.06.2014). 
noważonego rozwoju poszczególnych państw, które taktowane były jako drugorzędne wobec wskaźników makroekonomicznych, a w szczególności wobec PKB. W związku z tym HDI umożliwia dokonanie pełniejszej oceny rozwoju i dobrobytu niż PKB na jednego mieszkańca czy też inna miara ekonomiczna, zwłaszcza w przypadku, gdy jest analizowany wraz z odrębnymi wskaźnikami ${ }^{23}$ dotyczącymi między innymi rozwoju społeczno-gospodarczego i demograficznego oraz danymi zawierającymi informacje na temat poziomu zanieczyszczenia środowiska, bezpieczeństwa osobistego oraz innych aspektów życia w poszczególnych państwach. W związku z tym HDI określany jest również jako wskaźnik rozwoju społeczno-ekonomicznego oraz dobrobytu i stosowany jest przez ONZ do celów porównań międzynarodowych ${ }^{24}$.

HDI stanowi syntetyczną miarę obliczaną na podstawie średniej poszczególnych wskaźników zawierających się w trzech podstawowych płaszczyznach życia ${ }^{25}$ :

a) długie i zdrowe życie (long and healthy life) oceniane przez wskaźnik przeciętnej długości życia;

b) wiedza (knowledge) oceniana poprzez wskaźnik analfabetyzmu i skolaryzacji;

c) dostatni standard życia (decent standard of living) oceniany przy użyciu wskaźnika PKB per capita.

Sfery, z których składa się HDI, badane w ramach tego wskaźnika nie obejmują jednak wszystkich elementów zawartych w koncepcji rozwoju ludzkiego ze względu na niemożność pomiaru niektórych cech jakościowych lub brak odpowiednich danych źródłowych.

Poprzez wykorzystanie do obliczeń HDI odpowiedniej metodologii rekomendowanej przez UNDP stosowany jest on do określania poziomu rozwoju społeczno-gospodarczego, a co za tym idzie - również dobrobytu odrębnych krajów, dzięki czemu możliwe jest hierarchiczne uszeregowanie ich pod względem ogólnego poziomu rozwoju i określenie dystansu występującego pomiędzy państwami rozwijającymi się i rozwiniętymi.

Do obliczeń tego syntetycznego wskaźnika, jakim jest HDI, wykorzystywane są bezpośrednio cztery podstawowe mierniki, których odpowiednie zsumowanie klasyfikuje poszczególne państwa w skali $0-1$. Wśród tych wyznaczników wyróżnia się ${ }^{26}$ : przeciętne dalsze trwanie życia, ogólny wskaźnik solaryzacji brutto na wszystkich szczeblach nauczania, wskaźnik umiejętności czytania ze zrozumieniem i pisania oraz PKB per capita (PPP USD).

23 Raport o rozwoju spolecznym, $W$ trosce o prace, Polska 2004, s. 1.

24 www.gis.geo.uj.edu.pl/Teaching_tool_on_knowledge_transfer/pl/wskazniki.html (28.06.2014).

25 D. Nefs, HDI Project Report, Indie 2009, s. 2.

26 www.undp.iq.pl/Co-robimy/Badania-rozwoju-spolecznego2 (28.06.2014). 
Należy wskazać, iż podział poszczególnych krajów na słabo, średnio i wysoko rozwinięte przy uwzględnieniu wskaźnika HDI kształtuje się następująco ${ }^{27}$ :

- 0-0,5 - kraje słabo rozwinięte (zacofane),

- 0,501-0,8- kraje średnio rozwinięte,

- 0,801-1,0 - kraje wysoko rozwinięte.

Pozycję Polski na tle innych państw, w tym także państw zaliczanych do Unii Europejskiej, w kontekście rozwoju społecznego, w tym także dobrobytu, określa ranking ustalony według wartości HDI. Wiele procesów występujących w Polsce po 1989 roku uległo dynamizacji po akcesji do Unii. Szczególnie widoczne stało się to w takich sferach, jak edukacja, warunki zatrudnienia czy prawa konsumenta. Dzięki unijnym instytucjom infrastrukturalnym powstały nowe miejsca pracy, w wyniku czego fala emigracji zarobkowej radykalnie zmieniła kontekst polskiej reformy rynku pracy. Kształtowanie się HDI w Polsce na tle Unii Europejskiej przedstawiono na rysunku 3.

Rysunek 3. Kształtowanie się HDI w Polsce na tle Unii Europejskiej w latach 2005-2012

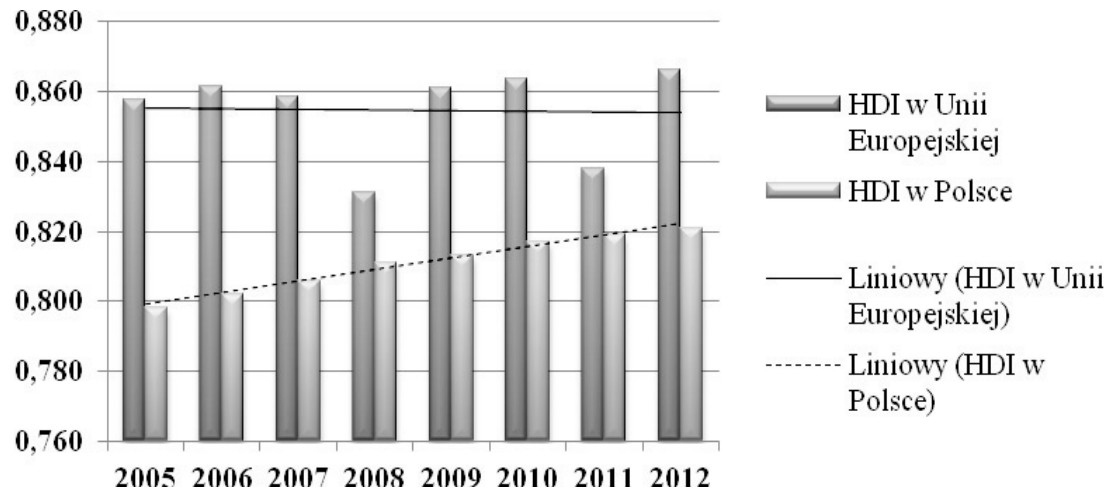

Źródło: opracowanie własne.

W latach 2005-2012 widoczny jest stopniowy wzrost HDI w Polsce. Niewattpliwie fakt ten jest związany z akcesją do Unii Europejskiej, która pociągnęła za sobą wiele pozytywnych przemian społeczno-gospodarczych. Od roku 2006 Polska znajduje się wśród krajów wysoko rozwiniętych, bowiem poziom HDI nieprzerwanie przekracza próg 0,801 szacowany dla krajów o wysokim rozwoju. Należy jednak zauważyć, iż średnia omawianego wskaźnika dla państw Unii jest w każdym roku wyższa niż w przypadku Polski, co wskazuje na konieczność podejmowania dalszych działań zmierzających do podnoszenia poziomu poszczególnych mierników będących składowymi HDI w celu poprawy pozycji Polski na tle krajów Unii Europejskiej.

27 W trosce o prace..., s. 3. 
Składająca się z ekonomistów międzynarodowa komisja zajmująca się badaniem mierników wyników gospodarczych, postępu społecznego oraz dobrobytu wskazała na liczne wady istniejących wskaźników i zaproponowała wiele nowych rozwiązań. Eksperci pracujący pod kierownictwem noblisty J. Stiglitza wysunęli wniosek, iż wąski miernik wyników rynkowych, jakim jest PKB, mylony jest z szerszymi miarami dobrobytu. J. Stiglitz i A. Sen opracowali dla Unii Europejskiej grupę wskaźników, które należy stosować jednocześnie, aby w pełni oddawały panującą sytuację gospodarczą. Wskazują oni na istotne kwestie, które powinny być uwzględnione przy konstruowaniu tego typu analiz, między innymi: zachorowalność na przewlekłe schorzenia, średnia długość życia, stopień zanieczyszczenia środowiska czy poziom ubóstwa.

W 2005 roku brytyjski tygodnik „The Economist” opracował wskaźnik jakości życia (Quality of Life Index - QLI) w celu odzwierciedlenia poziomu życia i satysfakcji życiowej w poszczególnych krajach. Uwzględnia on takie parametry, jak: sytuacja materialna, zdrowie, stabilność polityczna i bezpieczeństwo, życie rodzinne i wspólnotowe, klimat i geografia, bezpieczeństwo zatrudnienia, wolność polityczna i równość płci. Dysfunkcją tego miernika jest jednak to, że uwzględnia on jedynie sferę jakości życia. Wskaźnik ten łączy rezultaty ankietowania subiektywnej satysfakcji życiowej z obiektywnymi czynnikami jakości życia w różnych państwach ${ }^{28}$.

Na szczególną uwagę zasługuje stworzony przez OECD w 2011 roku wskaźnik lepszego życia (Better Life Index). Pozwala on na porównywanie dobrobytu we wszystkich krajach na podstawie takich kategorii, jak: warunki mieszkaniowe, nakłady finansowe, dochód, bezpieczeństwo pracy, wsparcie społeczne, edukacja, stan środowiska, zdrowie, bezpieczeństwo i zadowolenie z życia. Wszystkie te wyznaczniki OECD uznało za istotne z perspektywy oceny materialnych warunków i jakości życia ${ }^{29}$. Twórcy tego indeksu uważają, iż PKB nie ukazuje, jak żyje się i mieszka w danym kraju. Celem jednej z inicjatyw OECD nazywanej „Better Life” stało się zrozumienie mechanizmów pobudzających dobrobyt jednostek i społeczeństw. We współpracy z Komisją do spraw Pomiaru Wyników Gospodarczych i Postępu Społecznego określono jedenaście wymiarów dobrobytu, które stały się fundamentem do stworzenia nowego wskaźnika mającego szansę stania się alternatywą dla krytykowanych mierników opartych na systemie rachunków narodowych ${ }^{30}$. Wszystkie wskazane kryteria oceniane są dla każdego badanego państwa w skali 0-10 i prezentowane przez OECD za pomocą specyficznego wykresy pod postacią kwiatu, gdzie każdy kolor liścia oznacza inną ocenianą dziedzinę. Udział poszczególnych kryteriów wchodzących w skład Better Life Index w 2013 roku w Polsce zaprezentowano na rysunku 4.

28 www.economist.com/media/pdf/QUALITY_OF_LIFE.pdf (28.06.2014).

29 www.oecdbetterlifeindex.org (28.06.2014).

30 www.dobrobyt.info.pl/wskazniki-dobrobytu/wskaznik-lepszego-zycia-bli/272/ (28.06.2014). 
Rysunek 4. Poziom wskaźnika Better Life Index w Polsce w 2013 roku

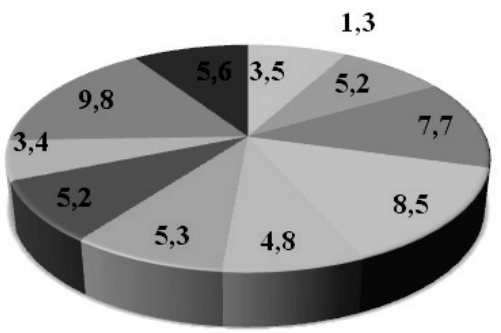

$\square$ Warunki mieszkaniowe i nakłady finansowe

$\square$ Dochód gospodarstwa domowego

$\square$ Zarobki, bezpieczenistwo pracy, bezrobocie

Jakość sieci wsparcia sp olecznego

تEdukacja

⿶Stan środowiska naturalnego

⿶Zaangażowanie obywatelskie

Q Zdrowie

Q $Z$ Zadowoleniez życia

$\square$ Bezpieczeństwo

-Balans praca-życie

Źródło: opracowanie własne na podstawie: www.oecdbetterlifeindex.org/countries/poland/ (29.06.2014).

Na podstawie rysunku 4 można zaobserwować, iż w przypadku wielu kryteriów dobrobytu wskazanych przez OECD Polska lokuje się znacznie poniżej średniej. Dotyczy to przede wszystkim dochodów $(1,3)$, zadowolenia z życia $(3,4)$ i sytuacji mieszkaniowej $(3,5)$. Dobre wyniki Polska uzyskuje natomiast w takich kategoriach, jak: bezpieczeństwo $(9,8)$, edukacja $(8,5)$ oraz jakość sieci wsparcia społecznego $(7,7)$. W tych indeksach Polska wyprzedza nawet Austrię będącą liderem, jeśli chodzi o poziom dobrobytu w ujęciu wskaźnika Better Life Index.

\section{Podsumowanie}

Mierzenie dobrobytu jest skomplikowanym i trudnym procesem wymagającym uwzględnienia nie tylko czynników ekonomicznych, ale także aspektów społecznych, politycznych i kulturowych. Od dłuższego czasu zauważalna jest intensywna krytyka w odniesieniu do PKB jako uniwersalnej miary dobrobytu ekonomicznego. Jednakże stworzenie alternatywnych wskaźników uwzględniających pomijane przez PKB obszary jest zadaniem złożonym i obarczonym dużym ryzykiem błędu. Powstałe do tej pory miary nie są pozbawione wad, choćby w takich aspektach, jak pomijanie sfery jakości 
życia czy brak uwzględniania czynników społecznych. W najbliższym czasie z pewnością powstanie wiele badań nad stworzeniem tego typu mierników.

Kontrowersje powstałe wokół PKB wynikają jednak z niesłusznego traktowania go jako miernika poziomu życia i dobrobytu. Ewolucja rachunków narodowych wynikająca ze zmian powstających w gospodarce globalnej prowadzi do tworzenia coraz dokładniejszych metod badań i szacunków.

W minionych dziesięcioleciach pojawiły się obawy, że takie wskaźniki makroekonomiczne jak PKB nie oddadzą w pełni tego, czym tak naprawdę jest dobrobyt w ujęciu ekonomicznym i społecznym. W związku z tym powstają alternatywne do niego mierniki oddające w większym bądź mniejszym stopniu skalę badanego problemu. Pomimo jednak licznych opracowań i podejść do oceny dobrobytu i jakości życia społeczeństwa nie udało się do tej pory znaleźć jednej uniwersalnej miary w tym zakresie.

\section{Literatura}

Cobb C., Halstead T., Rowe J., If the GDP is Up, Why is America Down?, Atletic Monthly, Washington 1995.

Czarny B., Podstawy ekonomii, PWE, Warszawa 2011.

Drabsch T., Measuring Wellbeing, Briefing Paper no. 4/2012, Sydney 2012.

Grzelak A., Makroekonomia w procesie integracji z Uniq Europejska, Wyższa Szkoła Integracji Europejskiej w Szczecinie, Szczecin 2002.

Mankiw N.G., Taylor M.P., Makroekonomia, PWE, Warszawa 2009.

http://www.india.jbs.cam.ac.uk/engagement/tataises/downloads/report_nefsd.pdf..

Samuelson P.A., Nordhaus W.D., Ekonomia 2, Wydawnictwo Naukowe PWN, Warszawa 1999.

Stiglitz J.E., Ekonomia sektora publicznego, Wydawnictwo Naukowe PWN, Warszawa 2004.

Raport o rozwoju społecznym $W$ trosce o prace, Polska 2004.

www.biznes.pwn.pl.

www.dobrobyt.info.pl.

www.economist.com/media/pdf/QUALITY_OF_LIFE.pdf.

www.epp.eurostat.ec.europa.eu.

www.firma.egospodarka.pl.

www.gis.geo.uj.edu.pl/Teaching_tool_on_knowledge_transfer/pl/wskazniki.html.

www.mg.gov.pl.

www.monitor-ekonomiczny.pl.

www.oecdbetterlifeindex.org.

www.pl.tradingeconomics.com/poland/gdp-per-capita.

www.prognostic.pl.

www.undp.iq.pl.

Zienkowski L., Co to jest PKB? Jego rola w analizach ekonomicznych i prognozowaniu, Elipsa, Warszawa 2001. 


\section{Streszczenie}

W artykule dokonano deskrypcji ekonomii dobrobytu oraz ściśle związanych z nią rachunków narodowych. Celem podjętych rozważań jest zweryfikowanie produktu krajowego brutto w kontekście optymalnego wskaźnika dobrobytu ekonomicznego oraz weryfikacja, który z dostępnych alternatywnych mierników poziomu dobrobytu najdokładniej odzwierciedla dobrobyt jednostek oraz społeczeństw. W pierwszej części artykułu przedstawiono teoretyczne ujęcie ekonomii dobrobytu. Druga część opracowania ma natomiast charakter empiryczny i stanowi eksplorację wybranych rachunków narodowych oraz pomiaru dobrobytu w kontekście Polski.

\section{Welfare economics. National accounts and measurement of wellbeing}

The article presents the welfare economics and closely related to national accounts. The aim of the discussion is to verify the Gross Domestic Product in the context of an optimal rate of economic wellbeing, as well as verification that the available alternative measures of prosperity accurately reflects the wellbeing of individuals and societies. In the first part of the paper presents a theoretical approach welfare economics. The second part of the study is an empirical and an exploration of some of the national accounts and the measurement of wellbeing in the context of Polish.

Translated by Agnieszka Łopatka 